\title{
Effect of Different Sowing Methods on the Growth Characters and Yield of Soybean in Vertisol - A Review
}

\author{
S. S. Dhakad ${ }^{1 *}$, K. V. Ramana Rao², Vinod K. Bhargava ${ }^{2}$, Gayatri Verma', \\ G. R. Ambawatia ${ }^{3}$, Vijay Agrawal $^{4}$, Sanjeev Verma ${ }^{5}$ and R. K. S. Tomar ${ }^{6}$ \\ ${ }^{1}$ RVSKVV-Krishi Vigyan Kendra, Shajapur (MP), India \\ ${ }^{2}$ ICAR-Central Institute of Agricultural Engineering, Bhopal (MP), India \\ ${ }^{3} R V S K V V$-College of Agriculture, Indore (MP), India \\ ${ }^{4}$ Directorate of Horticulture and Food Processing, Bhopal (MP), India \\ ${ }^{5} J N K V V$ - Krishi Vigyan Kendra, Betul (MP), India \\ ${ }^{6} R V S K V V$-Directorate of Extension Services, Gwalior (MP), India \\ *Corresponding author
}

\section{A B S T R A C T}

\section{Keywords}

Ridge \& furrow, FIRB,BBF and soybean

\section{Article Info}

Accepted:

15 April 2020

Available Online:

10 May 2020
The objectives of sowing operation are to put the seed along with fertilizer in rows at desired depth and seed to seed spacing, cover the seeds with soil and provide proper compaction over the seed. The machinery such as seed cum fertilizer drill with attachment of furrow irrigated raised bed (FIRB), broad bed furrow (BBF) and ridge \& furrow systems are used to sow the seeds on raised beds in a pulverized soil so as to allow easy emergence of seed with proper moisture availability and better drainage during excess rainfall events. Several researchers have studied the effect of seed cum fertilizer drill with attachment of Furrow Irrigated Raised Bed (FIRB), Broad Bed Furrow (BBF) and Ridge \& Furrow systems on water sensitive crop soybean. The present paper reviewed such studies to conclude the better sowing method on the growth and yield of soybean crop in vertisols of India.

\section{Introduction}

Soybean (Glycine max Merril) is an important commercial crop in Indian agricultural and oil industry and remarkably contributed to yellow revolution. Soybean accounted for 55.6 per cent of area under kharif oilseeds and 38 per cent of area under total oilseeds in the country during Triennium average Ending (TE) 201213. The crop contributes to 62.5 percent of the kharif oilseed production and 47 per cent of total oilseeds production in the country, about 28.6 percent of the total vegetable oils and two-thirds of the oil meals supplies during the 
corresponding period. Even after being a leading oilseed crop, the yield level is well below the potential and almost stagnated at around 10-11 qt/ha in the country (Sharma et $a l ., 2016)$. Due to scanty and untimely rainfall during soybean growing season i.e., kharif, the productivity of soybean is decreasing year after year. The farmers are therefore, in search of new methods of sowing so that the soybean crop can perform better under excess as well as deficit rainfall conditions. One such method adopted by the farmers is the tractor operated furrow irrigated raised bed (FIRB) system in which two raised beds are prepared while sowing is carryout simultaneously on these raised beds.

Fertilizer drilling can also be accomplished on these raised beds while crop is sown. This raised bed planter is capable of making furrows of desired depth and width at both the sides of the bed and can be used for simultaneous sowing of crop in one operation. These furrows are useful to drain out excessive rainwater during heavy storms and for storing rainwater in furrows for enriching soil moisture through percolation in case of deficit rainfall and the soil moisture thus stored sustain the crop during dry spells (Singh et al., 2011).

The planting of soybean on altered land configuration [broad bed furrow (BBF) or furrow irrigated raised bed system (FIRBS)] or opening of conservation furrow each after $3 / 6$ rows may reduce the deleterious effect of both extreme situations (deficit and excess) of rains and the raised bed and sunken bed is also beneficial system in saline soils to grow soybean on raised bed and water loving crop like paddy in sunken beds (Billore et al., 2018). Land treatments (raised sunken bed system, ridges and furrows, broad bed and furrows) increased in situ soil moisture conservation, minimized runoff and soil erosion (Singh et al., 1999, Nagavallemma et $a l ., 2005)$ and increased the yield of principal crops grown in the region (Mandal et al., 2005, Rajput et al., 2009). Madhya Pradesh is endowed with well distributed rains ranging from 700 to $1200 \mathrm{~mm}$. Vertisols with good moisture holding capacity can be used to grow short-duration soybean by adopting sound land management practices such as broad bed and furrow system, Ridge and furrow. The adoption of proper land configuration system will help increase income to the farmers besides preventing land degradation due to runoff erosion (Tomar et al., 2011).

The research information on predominant cropping systems (soybean-wheat and soybean-chick pea) on BBF and FIRB systems with integrated nutrient management over years has established that the practice not only helped in retention of higher moisture in the profile, but also enhanced yield and soil quality in terms of increased soil organic matter stock, fertility status and physical, chemical and biological indicators of soil quality (Ramesh et al., 2006 and 2007).

Different sowing methods viz. furrow irrigated raised bed (FIRB), broad bed furrow (BBF) and ridge \& furrow systems ensure better drainage, safe disposal of runoff which were found effective in sustainable crop production and also for enhancing resource use efficiency

\section{Effect of furrow irrigated raised bed (FIRB) on performance of soybean}

Raut et al., (2000) studied different sowing methods in soybean flat bed; raised beds $(1,2$, 3 and 4 rows), and ridges (one row top, one and two rows)] and reported significant differences among the different sowing methods for the number of pods plant ${ }^{-1}$ and seed yield. However, plant height and 100 seed weight were not significantly varied. A 
significantly high number of pods plant ${ }^{-1}$ was recorded from the raised bed sowing with one row. Pod numbers in the flat bed method, raised bed method with 3 and 4 rows and ridges with 2 rows on both sides were at par with each other and were lower than those in other methods. The highest seed yield average (3347 $\mathrm{kg} \mathrm{ha}^{-1}$ ) was recorded from ridges method with 2 rows on both sides.

Singh et al., (2012) studied the comprised two treatments with ten replications. The treatments consisted of sowing by the tractor operated FIRBS seed drill and flat sowing. A tractor operated FIRBS seed drill was fabricated suiting to Vertisols and farm validated for facilitating development of raised beds along with sowing operations on the raised bed. Planting of soybean using FIRBS seed drill resulted in 20.48 per cent increase in plant population and resultant seed yield by 21.93 percent. The additional cost of FIRBS $(14,000)$ over normal seed drill $(44,000)$ can be recovered in 2.3 years. The FIRBS made by the machine is capable of mitigating the effect of dry spells as well as water logging conditions. A significant higher seed yield was observed when used FIRBS machine over flat sowing. The recorded yield ranged between 1251 to $1350 \mathrm{~kg}$ per ha on FIRBS plots as compared to 1035 to $1082 \mathrm{~kg}$ per ha on flat plots.

Jha et al., (2014) studied the effect of drainage, tillage and land configurations on root, nodules and yield of Soybean in Vertisols in the JNKVV farm with the collaboration of Japan International Corporation Agency (JICA) in 2012. and revealed that that net returns (Rs 50,682/ha) and $\mathrm{B}: \mathrm{C}$ ratio (2.75) were higher for the conventional tillage + raised bed + open drainage channel treatment than other method combinations. All the method combinations in late sowing showed minimum net returns and $\mathrm{B}: \mathrm{C}$ ratio due to low seed and straw yields.
From results, it can be concluded that the conventional tillage + raised bed + open drainage channel treatment is a suitable combination for better seed and straw yields and that the no till treatments combined with drainage methods can improve soybean root growth and nodule number.

Dhakad (2016) studied the effect of raised bed planting on the growth characters and yield of soybean in Dhar district of MP. The On farm testing were conducted in Dhar district of Madhya Pradesh during 2013 to assess the effect of raised bed planting on growth characters and yield of soybean crop. The analysis revealed that the yield (1606 kg ha $\left.{ }^{-1}\right)$ was recorded significantly higher under raised bed planting compared to normal flat bed sowing (1205 kg ha ${ }^{-1}$ ) which subsequently resulted in yield enhancement to the extent of $33.3 \%$ for soybean. Gupta et al., (2018) studied the influence of furrow irrigated raised bed seed drill on growth characters and yield of soybean (Glycine $\max$ L.) in Mandsaur district of Madhya Pradesh.

The field trials were conducted during the two consecutive years 2014-15 and 2015-16 at farmer's field in Daludarail and Gurjarbardia villages of Mandsaur district of Madhya Pradesh to assess the effect of furrow irrigated raised bed (FIRB) seed drill on the growth characters, yield and economic parameters of soybean cultivation. The FIRB seed drill was found superior in terms of plant population, number of branches per plant at 60 DAS, number of root nodules per plant at 60 DAS, number of pods per plant at harvest, seed index and harvest index as compared to conventional seed drill. Though, less consumption of fuel (28.35 1/ha) was recorded in conventional seed drill but the productivity of soybean was observed highest in FIRB seed drill (1318 kg/ha) whereas, it was found lowest in conventional seed drill (1103 $\mathrm{kg} / \mathrm{ha}$ ). 
The higher net return of 25792 Rs/ha with $\mathrm{B}: \mathrm{C}$ ratio of 2.36 was recorded for soybean cultivation under FIRB drill as compared to lower net return $18735 \mathrm{Rs} / \mathrm{ha}$ with $\mathrm{B}: \mathrm{C}$ ratio of 2.00 for soybean cultivation under conventional seed drill. Singh et al., (2018) conducted field experiments during the Kharif season of 2014-15, 2015-16 and 2016-17 at KVK, Indore to study the effect of different land configuration on the yield of soybean. The experiment consisted of three treatments of land configuration, viz., T1 (FIRBS layout), T2 (Ridge and furrow layout), T3 (BBF layout), under RBD design with seven replications. Result showed that significant increase was observed in yield contributing characters viz., number of pods plant-1, 100 seed weight $(\mathrm{g})$, seed yield (q ha-1) and harvest index (\%) in FIRBS layout as compared to ridges and furrow and broad bed furrow. The net returns are the best index of profitability of soybean crop and higher net returns per ha of Rs. 24699 was recorded for soybean crop under the FIRBS whereas lower net returns per ha of Rs. 20808 was recorded under BBF land configuration. Effect of FIRBS sowing method in soybean crop was found better in comparison with ridge and furrow as well as broad bed furrow method. The FIRBS sowing method recorded net return significantly higher over the ridge and furrow and broad bed furrow for soybean crop. The results of experiment indicated that for achieving higher productivity of soybean crop, the soybean crop should be sown in furrow irrigated raised bed system (FIRBS).

Gupta and Basediya (2019) studied the influence of different seed bed configurations on growth characters and yield of soybean (Glycine max L.) in Malwa Region of Madhya Pradesh. The field trials were conducted during the two consecutive years Kharif 2017 and Kharif 2018 at farmer's field in Gogarpura, and Guradia deda villages of Mandsaur district of Madhya Pradesh to assess the effect of different seed bed configurations on growth characters and yield of soybean. The experiment consists of three seed bed configurations i.e., flat bed sowing at $45 \mathrm{~cm}$ inter row spacing (T1), raised bed of $90 \mathrm{~cm}$ with 3 crop rows per bed (T2) and raised bed of $60 \mathrm{~cm}$ with 2 crop rows per bed (T3) with ten replications. The treatment T3 was found significantly superior in terms of plant height, number of root nodules per plant at flowering, number of pods per plant, grain yield, straw yield and harvest index as compared to treatments $\mathrm{T} 1$ and $\mathrm{T} 2$. The grain yield was found maximum in treatment T3 $(16.73 \mathrm{q} / \mathrm{ha})$ followed by treatment $\mathrm{T} 2$ $(14.88 \mathrm{q} / \mathrm{ha})$ and treatment T3 $(14.71 \mathrm{q} / \mathrm{ha})$. The treatment raised bed of $60 \mathrm{~cm}$ with $2 \mathrm{crop}$ rows per bed (T3) recorded highest net return of $38455 \mathrm{Rs} / \mathrm{ha}$ with $\mathrm{B}: \mathrm{C}$ ratio of 2.91 was found economically feasible as compared to other seed bed configurations in Malwa Region of Madhya Pradesh. It can be concluded that the practice of soybean cultivation on raised seed bed configurations was found superior in comparison with flat bed method of sowing.

The results of the study indicated that the higher productivity with maximum net return of soybean cultivation can be achieved by raised seed bed configurations as compared to flat bed method of sowing in Malwa region of Madhya Pradesh. Dhakad et al., (2020) conducted field experiments during the two consecutive years 2014-15 and 2015-16 at farmer's field in Shajapur district of Madhya Pradesh to assess the effect of raised bed planting on the growth characters, yield and economic parameters of soybean crop. The field trials were conducted during kharif season 2014 to 2015 for soybean crop to assess furrow irrigated raised bed (FIRB) seed cum fertilizer drill. Furrow irrigated raised bed (FIRB) seed cum fertilizer drill was found better in term of growth characters and yield of soybean in comparison with 
conventional seed drill. The net return is the best index of profitability of soybean crop and higher net return per ha Rs 34533 was recorded for soybean crop under raisedbed planting where as lower net return per ha of Rs 18971 was recorded for soybean crop under control.

\section{Effect of ridge and furrow system and on performance of soybean}

Beneficial effects of ridge and furrow method of sowing on soybean yield have been attributed to improved soil aeration, moisture, temperatures, better root development and nitrogen fixation (Tisdall and Hodgson, 1990; Jayapaul et al., 1995; Jain and Dubey, 1998; Raut et al., 2000).

Patil et.al.(2006) conducted field study during kharif season of 2006 on effect of mulching and land configuration on growth and yield of soybean (Glycine max L.) and revealed that growth characters like leaf area/plant and number of branches/plant were significantly influenced by different treatment of mulching and land configuration. Also among the different land configuration treatments, ridges and furrows method of planting soybean recorded significantly higher values of all yield contributing characters and yield of soybean. Ram \& Singh. (2011) conducted an experiment on four sowing methods namely raised bed planting, raised broad bed planting, ridge-furrow sowing and flat sowing for soybean crop. The highest seed yield was recorded in raised bed sowing, which was 6.70 and $5.29 \%$ higher than ridge furrow and flat sowing methods, respectively. Tomar (2012) concluded that insitu moisture conservation practice i.e. ridge and furrow imparted beneficial effect of soybean to getting higher yield and net return under erratic rainfall condition of Bundelkhand zone of M.P. Singh et al., (2012) studied the the effect of planting by tractor-drawn sweep seed drill, on growth and yield performance of soybean, weed population and economics. A Tractor drawn sweep seed drill, attachable on 30 PTO hp tractor was conceived, fabricated and validated for facilitating weeding along with sowing operations on the field prepared for soybean crop. The use of developed seed drill leads to saving of one pass tillage and one weeding operation in the initial growth period. In this way, approximately 3 000/ha/season could be saved from the total expenditure. The simultaneous tillage and sowing operation by the machine helps to maintain higher plant population (25.22-34.55\%). This also leads to reduction of weeds $(59.91-68.37 \%)$ as compared to flat sowing method.

Thus, the use of sweep seed drill curtails the cost on post sowing weedicides along with seed bed preparation as one operation of cultivator. Result of the study indicated that crop planted by the sweep seed drill showed yield increase from 7.78 to $16.46 \%$ as compared to normal seed drill. It is suggested to get tractor-operated sweep seed drill manufactured with an adjustable frame which could hold sweeps at the rear end of the frame of the seed drill and the tines for dropping seeds on the front of the seed drill frame to ensure better field operation. Lakpale and Tripathi (2012) studied the best combination of sowing on different land configuration systems and seed rates of soybean under high rainfall conditions of Chhattisgarh. Results revealed that growth parameters, yield attributes and seed yield of soybean were the highest under ridge and furrow sowing. Seed yield of soybean was unaffected due to different seed rates. Sowing on ridge and furrow $(2248 \mathrm{~kg} / \mathrm{ha})$ and seed rate of $62.5 \mathrm{~kg}$ per ha $(2071 \mathrm{~kg} / \mathrm{ha})$ was resulted in highest yield over rest of the treatments. The economic (net returns- Rs 22,880 and CB ratio 2.57 ) were maximum under ridge and furrow planting. 
Alternatively, broad-bed planting with 4 rows with seed yield of $(2214 \mathrm{~kg} / \mathrm{ha})$ offering net returns of Rs 33,520 with $\mathrm{B}: \mathrm{C}$ ratio of 3.50 should be the preferred method over other methods. Planting on flat land led to lowest seed yield (1690 kg/ha) and economic benefits (net returns - Rs 15,640 and B: C ratio - 1.84).

Bhargav et al., (2013) studied in which seed is placed on the surface and covered with soil from both sides to make the ridge on the seed. To make the ridge and furrow, an extra sweep blade (punji) was attached on the back tines of existing seed-cum-fertilizer drill machine. Soil moisture content was estimated at various depths viz. 10, 20,30, 40 and $50 \mathrm{~cm}$, and at 15, 30, 45 and 60 days after sowing. The soil moisture at the depth of $30-40 \mathrm{~cm}$ during flowering stage under prevalent method of sowing was found as $18 \%$ whereas under ridge and furrow system of planting, it was recorded as $21 \%$. The study result indicated the increase in production of soybean in the tune of $10-15 \%$ more than that of prevalent method of planting seeds. Dhakad et al., (2014) studied ridge and furrow system for soybean crop at farmer's fields in Vidisha district under Vindhya plateau agro-climatic region of Madhya Pradesh. Result showed that growth character found higher in ridge and furrow system compared to the normal flat bed sowing which subsequently resulted in yield enhancement to the extent of $27.2 \%$ for soyabean crop.

Dhakad et al., (2015) studied the effect of ridge and furrow system on growth characters and yield of rainfed soybean (Glycine $\max$ L.) in Madhya Pradesh. Field experiments were conducted in Dhar district of Madhya Pradesh during 2011 and 2012 to assess the effect of ridge and furrow planting on growth characters and yield of soybean crop. The ridge and furrow planting was better in term of growth parameters, seed yield and straw yield in comparison with normal flat bed sowing for soybean crop. Economic analysis revealed that the net profit (Rs. 28150 ha) was recorded higher under ridge and furrow planting as compared to normal flat bed sowing (Rs. 17889 ha) for soybean crop in pooled data analysis.

Basediya et al., (2018) studied the performance of ridge and furrow system on the growth and yield attribution of soybean in Barwani district of M.P. India. The field experiment was conducted during the two consecutive Kharif seasons of 2011 and 2012 to study ridge and furrow in-situ conservation system for soybean crop at farmer's fields in Badwani district of Madhya Pradesh under Nimar agro-climatic region. Result showed that growth and yield contributing character viz. plant population, plant height, root length, root nodules, pods per plant, seed yield weight per plant, seed yield, straw yield and harvest index $(\%)$ found higher in ridge and furrow system compared to the normal flatbed sowing method which subsequently resulted in yield enhancement to the extent of 8-23\% for soybean crop.

Economic analysis revealed that the net profit was recorded higher under ridge and furrow system compared to normal flatbed sowing. $\mathrm{B}$ : $\mathrm{C}$ ratio was recorded as 3.35 and 3.23 under ridge and furrow system while 2.83 and 2.77 under flat sowing system for the year of 2011 and 2012 respectively. It is concluded that ridge and furrow sowing of soybean should be advocated over flatbed sowing mainly due to the soil moisture stored sustains the crop during dry spells.

Dhakad et al., (2019) studied the effect of ridge and furrow seed cum fertilizer drill on growth characters and yield of soybean (glycine max) in shajapur district of Madhya Pradesh. A field experiments was conducted 
during kharif season 2016 to 2017 for soybean crop to assess ridge and furrow seed cum fertilizer drill. Seed-cum-fertilizer drill was found better in term of growth characters and yield of soybean in comparison with simple seeddrill sowing machine. The highest productivity of $1309 \mathrm{~kg} \mathrm{ha}^{-1}$ observed in the seed cum fertilizer drill sowing whereas lowest under normal seeddrill sowing (1091 $\mathrm{kg} \mathrm{ha}{ }^{-1}$ ) for soybean crop. The net return is the best index of profitability of soybean crop and higher net return per ha Rs 25144 was recorded for soybean crop under ridge and furrow attach seed cum fertilizer drill where as lower net return per ha of Rs 18025 was recorded for soybean crop under normal seed drill sowing. The plant height, number of branches per plant, number of root nodules per plant, number of pods per plant, seed yield, straw yield and net monetary returns were statistically higher in seed cum fertilizer drill sowing compare to normal seed drill sowing for soybean crop. The analysis showed that there was no significant difference on seed index, grain straw ratio and harvest index due to treatments was observed.

Basediya et al., (2020) studied the effect of ridge and furrow system on soybean cultivation in Shivpuri district of M.P. The field study through front line demonstration was carried during the two consecutive Kharif 2015 and Kharif 2016 to study the effect of ridge and furrow system for soybean crop at farmer's fields in Shivpuri district of Madhya Pradesh under gird agro-climatic zone. Result showed that growth character (plant population, plant height, root length, number of root nodules per plant) and yield contributing character viz., pods per plant, seed yield, straw yield and harvest index (\%) found higher in ridge and furrow system over to the normal line sowing method. Net profit was recorded higher under ridge and furrow system as compared to normal flat bed sowing. Average yield in ridge and furrow system was recorded as $11.73 \mathrm{q} / \mathrm{ha}$ over conventional line sowing system as $9.01 \mathrm{q} / \mathrm{ha}$. Average B: C ratio was recorded as 1.99 under ridge and furrow system while 1.54 under normal line sowing system. The results of experiment indicated that ridge and furrow system recommended for achieving higher productivity of soybean crop in Shivpuri district of Madhya Pradesh in excess and dry spell both extreme situations.

\section{Effect of broad bed furrow (BBF) system on performance of soybean}

Singh et al., (2011) studies the tractor-drawn broad bed furrow (BBF) seed drill machine for soybean [Glycine $\max$ (L.) Merrill] was conceived, fabricated and farm validated. It effectively operates in Vertisols and associated soils and is attachable to the tractor for facilitating formation of broad bed along with furrows on both the sides of the beds of desired width and depths and subsequent sowing in one go. Plant population mortality in soybean with tractor-drawn BBF seed drill for Vertisols was reduced in the range of 14$19 \%$ as compared to flatbed under the vagaries of monsoon which subsequently resulted in enhancement to the extent of $18.65 \%$. Study also indicated that tractoroperated BBF seed drill specifically fabricated for individual tractor performed better in Vertisols and under prevailing field draft conditions.

Gupta et al., (2017) studied the influence of broad bed furrow seed drill on growth characters and yield of soybean (Glycine max L.) in Mandsaur district of Madhya Pradesh. The field experiments were conducted during the two consecutive years 2014-15 and 201516 at farmer's field in Daludarail and Gurjarbardia villages of Mandsaur district of Madhya Pradesh to assess the effect of broad bed furrow $(\mathrm{BBF})$ seed drill on the growth characters and yield of soybean. The BBF 
seed drill was found better in terms of plant population, number of branches per plant at 60 DAS, number of root nodules per plant at 60 DAS, number of pods per plant at harvest, seed index and harvest index as compared to conventional seed drill. The productivity of soybean was observed highest in BBF seed drill $(1312 \mathrm{~kg} / \mathrm{ha})$ whereas it was found lowest in conventional seed drill (1121 $\mathrm{kg} / \mathrm{ha}$ ). The higher net return of $26580 \mathrm{Rs} / \mathrm{ha}$ with B:C ratio of 2.41 was recorded for soybean cultivation under $\mathrm{BBF}$ drill as compared to lower net return $18100 \mathrm{Rs} / \mathrm{ha}$ with $\mathrm{B}: \mathrm{C}$ ratio of 1.97 for soybean cultivation under conventional seed drill.

Asewar et al., (2017) conducted to find out the effect of various land configurations and nutrient cum stress management practices on growth and yield of soybean. The experiment was designed in split plot design with three replications. The main plot treatment comprised of three land configuration i.e. $\mathrm{BBF}$, ridges and furrows and flat bed with eight sub plot treatments fertilizer cum stress management practices. The gross and net plot sizes are $5.4 \times 6.0 \mathrm{~m}$ and $4.5 \times 5.0 \mathrm{~m}$ respectively. The soybean variety MAUS-162 was used for sowing with spacing of $45 \mathrm{x}$ $5 \mathrm{~cm}$. In case of land configuration, the pooled results revealed that yield attributing parameters like number of pods per plant, seed weight per plant, pod weight and seed index were found highest in soybean sown on Broad bed furrow as compared to flat bed and ridges and furrow. In case of fertilizer cum stress management practices, RDF + KNO3@ 1 and $2 \%$ and RDF micronutrient mixture @ $0.5 \%$ recorded higher yield attributing characters in pooled analysis. Highest soybean seed yield, GMR, NMR and BC ratio was observed with soybean sown on $\mathrm{BBF}$ land configuration in pooled analysis. In case of fertilizer cum stress management practices, $\mathrm{RDF}+\mathrm{KNO} 3 @ 1 \& 2 \%$ and RDF + micronutrient mixture @ $0.5 \%$ recorded higher soybean seed yield, GMR, NMR and $\mathrm{BC}$ ration in pooled analysis. Higher rain water use efficiency was recorded in BBF sowing and RDF + KNO3spray @ 1 and 2\%. Higher moisture content was observed in soybean sown with BBF as compared to flat bed and ridges and furrow method. It is concluded that BBF technique is proved as climate smart technique for growing of soybean under rainfed condition. Broad bed furrow system (BBF) with RDF plus foliar application of $\mathrm{KNO} 3$ micronutrients mixture was proved to be the most significant climate smart technology for rainfed soybean in Marathwada region

Verma et al., (2018) concluded that plant population ranged 9-10 per cent higher on planting soybean using broad bed furrow seed cum fertilizer drill machine as compared to sowing by normal seed drill. The number of pods per plant, pod length and seed index were observed 47.21, 4.68 and 5.79, respectively in broad bed furrow system. B: C ratio was 3.13 for $\mathrm{BBF}, 1.79$ for flat bed sowing and 2.99 for inclined plate planting in Bhatapara District of Chhattisgarh. Motwani and Ashish (2018) concluded that maximum average seed yield of soybean under broad bed furrow planting was $1,832 \mathrm{~kg}$ per ha in 2016 and $1,964 \mathrm{~kg}$ in 2017 for broad bed furrow while under farmer practices $1475 \mathrm{~kg}$ per ha in 2016 and $1605 \mathrm{~kg}$ per ha in 2017 yield obtained in Vertisols and associated soils. The average gross returns in case of broad bed and furrow planting (Rs 56,777 and 59,893 per ha during 2016 and 2017, respectively) which count 22 to $24 \%$ higher than farmers" practice. Singh et al., (2019) studied the impact of better management practices on performance of Soybean in Madhya Pradesh and concluded that the planting of soybean on changed land configuration (BBF and Ridges and Furrow system) has added advantage over flat land planting by way of mitigating adverse effect 
of moisture stress and thereby improving the yield levels of soybean. The improvement in performance of crop and monetary benefit can be harnessed by the farmers by adaptation of improved technology and varieties. Jain (2019) conducted demonstrations for two years (2017-2018) on Vertisols and associated soils in Mandsaur and Neemach region of Madhya Pradesh revealed that planting soybean on altered land configuration (broad bed furrow system) enhances the productivity by 21.19 per cent as compared to farmers practice of flat bed planting. The higher additional returns (Rs 10,444/ha) were achieved over farmer's practice in case of former. The benefit cost ratio of (3.00) in broad bed furrow system was also higher than farmer's practice (2.64). Later maturing variety (JS 93- 05) gave higher yield (1,921 $\mathrm{kg} / \mathrm{ha}$ ) and additional returns (Rs 10,995/ha) as compared to early maturing JS 95-60 $(1,840 \mathrm{~kg} / \mathrm{ha}$ and Rs 10,179/ha). Comparison additional yield between flatbed planting (167 $\mathrm{kg} / \mathrm{ha}$ ) and broad bed furrow planting (323 $\mathrm{kg} / \mathrm{ha}$ ), both with improved technology brought out that change in planting method led to 103 per cent increase in additional yield in the latter case, suggesting that serious attempts to be made to popularize this technology to realise higher yield and monitory returns to farmers.

\section{Effect of seed cum fertilizer drill on performance of soybean}

Nimje et al., (2003) concluded that use of improved seeding machines such as seedcum-fertilizer drill and strip-till seed-cumfertilizer drill reduced the cost of operation by Rs 935 and Rs 1,578/ha and increased the net income by Rs 2,589 and Rs 3,703/ha, respectively, over the local seed drills used by the farmers. They also colclude that planting density of 440,000/ha increased the seed yield by $61.6 \%$ and the net returns by Rs $6,669 /$ ha over farmers' practice in farmers field in
Bhopal district. Dhakad and Khedkar (2014) was conducted field demonstration during kharif season 2012 to 2013 to study effect of seed-cum-fertilizer drill sowing machine for soybean crop at farmer's fields in tribal area in Dhar district of Madhya Pradesh. Soybean sown by seed-cum-fertilizer drill was found better in term of growth character (plant population, plant height, number of branches per plant and number ofroot nodules per plant) and seed yield weight par plant, seed index, seed yield, straw yield and harvest index (\%) comparison with simple seed drill sowing machine.

Dhakad et al., (2017) concluded that Seedcum-fertilizer drill was found better in term of growth characters and yield of soybean in comparison with simple seed drill sowing machine. The net return is the best index of profitability of soybean crop and higher net return per ha of Rs. 25569 was recorded for soybean crop under seed cum fertilizer drill whereas lower net return per ha of Rs. 17188 was recorded under normal seed drill sowing. Dhakad et al., (2015) and Dhakad et al., (2017) concluded that effect of seed-cumfertilizer drill sowing of wheat and soybean crop was found better in comparison with normal seeddrill sowing. Seed-cum-fertilizer drill sowing recorded net return significantly higher over the normal seeddrill sowing for wheat and soybean crop. The results of experiment indicate that for achieving higher productivity crop in tribal area under Dhar district of Madhya Pradesh, the wheat and soybean crop should be sown by seed-cumfertilizer drill sowing machine.

Several investigations have proved the benefits of adopting different sowing methods for obtaining higher soybean yields due to untimely and erratic rainfall conditions prevailed in Central India. The present review concludes that depending upon the availability of machinery as well as sowing 
time the farmers can adopt Furrow Irrigated Raised Bed (FIRB) or Broad Bed Furrow (BBF) or Ridge and Furrow methods of soybean sowing for obtaining economically viable returns from soybean crop.

\section{References}

Asewar B.V. A. K. Gore, M. S. Pendke, D. P. Waskar, G. K. Gaikwad, G. Ravindra Chary, S. H. Naraland M. S. Samindre. 2017. Broad Bed and Furrow Technique- A Climate Smart Technology for Rainfed Soybean of Marathwada Region. J. Agric. Res. Technol., 42 (3) : 005-009

Basediya, A.L, Kumar, P, Gupta, Rajesh., Bhargava, M.K., Singh, P. and Kushwaha, N.K. 2020. Study the effect of ridge and furrow system on soybean cultivation in Shivpuri district of M.P. Int. Arch. App. Sci. Technol. 11(1): 111-115.

Basediya, A.L., Mishra, Sunita., Gupta, Rajesh., Kumar, P. and Basediya, S.S. 2018. Performance of ridge and furrow system on the growth and yield attribution of soybean in Barwani District of M.P. India. Int. J. Curr. Microbiol. App. Sci. 7(8): 499-505.

Bhargav K S, V K Jain and Umat R. 2013. Ridge and furrow system of planting seeds: A water management approach for increased soybean production in Madhya Pradesh. Journal of Interacademicia 17(2): 245-253

Billore SD, BU Dupare and Purshottam Sharma 2016. Addressing Climate Change Impact on Soybean through Resilient Technology . Soybean Research 16(1 \& 2): 1-24

Dhakad S.S., G.R. Ambawatia and N.S. Khedkar 2017. Effect of seed cum fertilizer drill on Growth Characters and Yield of Soybean (Glycine Max) in Shajapur District of Madhya Pradesh. International Journal of Agricultural Engineering, 10(1) : 16-21

Dhakad SS 2016. Effect of raised bed planting on the growth characters and yield of soybean (glycine max) in Dhar district of MP. Environment and Ecology, 34 (1A) :384387

Dhakad SS, AK Badaya, Rajiv Umat and DK Paliwal. 2015. Performances of seed cum fertilizer drill for wheat crop in tribal area of Madhya Pradesh. Research in Environment and Life Sciences , 8 (4) 669672

Dhakad SS, Vijay Agrawal and SK Verma 2014. Effect of ridge and furrow system on the growth character and productivity of rainfed soybean in Vidisha district of M.P. Research in Environment and Life Sciences ,7 (3) : 211-212

Dhakad, S.S. and Khedkar, N.S. 2014. Influence of seed-cum-fertilizer drill machine on the growth characters and yield of soybean (Glycine max L.) at farmer's fields. Internat. J. Forestry \& Crop Improv., 5 (2) : 68-72

Dhakad, S.S., Badaya, A.K., Chouhan, S.S. and Gathiye, G.S. 2015. Effect of Ridge and Furrow System on Growth Characters and Yield of Rainfed Soybean (Glycine Max) in Madhya Pradesh. Indian Journal of Ecology. 42(1): 230-232.

Dhakad, S.S., G.R. Ambawatia, Mukesh Singh and Gayatri Verma. 2019. Effect of Ridge and Furrow Seed cum Fertilizer Drill on Growth Characters and Yield of Soybean (Glycine max) in Shajapur District of Madhya Pradesh, India. Int.J.Curr.Microbiol.App.Sci. 8(04): 22982304

Dhakad. S. S., Vijay Agrawal, K.S. Kirar, S.S. Chauhan and Sanjeev Verma. 2020. Performance of Soybean (Glycine max) under Raised Bed Planting in Malwa region of Madhya Pradesh, India. Int.J.Curr.Microbiol.App.Sci. 9(03): 31813186.

Gupta, Rajesh and Basediya, A.L. 2019. Influence of different seed bed configurations on growth characters and yield of soybean (Glycine $\max$ L.) in Malwa Region of Madhya Pradesh. Bull. Env. Pharmacol. Life Sci., Vol. 8 (9): 75-79.

Gupta, Rajesh., Gupta, B.S., Kulmi, G.S., Somvanshi, S.P.S. and Basediya, A.L. 2017. Influence of broad bed furrow seed drill on growth characters and yield of soybean (Glycine $\max$ L.) in Mandsaur district of Madhya Pradesh. Progressive Research - An International Journal Vol. 12 (Special-IV): 2675-2678. 
Gupta, Rajesh., Kulmi. G.S., Basediya, A.L. and Jadav, Mohan 2018. Influence of furrow irrigated raised bed seed drill on growth characteristics and yield of soybean in Mandsaur district of Madhya Pradesh, India. Plant Archives 18(1): 320-324.

Jain Manoj 2019. Yield Potentials of Soybean on Altered Land Configuration. Soybean Research 17(1\&2): 77-82

Jain, M.P. and Dubey, A.K. (1998). Productivity and economic viability of soybean with respect to planting systems and cultivars in Vertisol. Crop Research 16:102-22

Jayapaul, P., Uthayakumar, B., Devasagayam, M.M., Pandit, B.J., Palchamy, A. and Balakrishanan, A. 1995. Effect of land configuration methods, irrigation regimes and soil moisture conservation amendments on soybean (Glycine max L. Merrill) yield and quality characters. Crop Research 11: 253-57.

Jha A K , B S Dwivedi , A K Shrivastava , M Soni , K Taniwaki , T Kokuryu , I Kitagawa , K Tateishi , $\mathrm{K}$ Tsuji And S Kobayashi.2014.Effect of Drainage, Tillage and Land Configurations on Root, Nodules and Yield of Soybean in Vertisols. Soybean Research (Special Issue): 194-198: 2014

Lakpale Rajendra and Vivek Kumar Tripathi 2012. Broad- bed Furrow and Ridge and Furrow Method of Sowing under Different Seed Rates of Soybean (Glycine Max L.) for High Rainfall Areas of Chhattisgarh Plains Soybean Research 10 (1): 52-59

Mandal D K, Mandal C and Venugopalan M V. 2005. Suitability of cotton cultivation in shrink-swell soils in central India. Agricultural Systems 84: 55-75.

Motwani and Ashish 2018. Performance of Soybean Planted on Broad Bed Furrow System under Real Farm Conditions. Soybean Research 16 (1\&2): 113-117

Nagavallemma K P, Wani S P, Reddy M S and Pathak P. 2005. Effect of landform and soil depth on productivity of soybeanbased cropping systems and erosion losses in Vertic Inceptisols. Indian Journal of Soil Conservation 33(2): 132-6

Nimje P.M., Agrawal Vijay, Soni R.D.

2003.Effect of planting density and improved seeding machinery on yield and economics of soybean (Glycine max). Indian Journal of Agronomy.48 (4):301-304

Patil,B., Chorey, A. B., Deshmukh, M. R., Karunakar, A. P., 2006.Effect of mulching and land configuration on growth and yield of soybean, Plant Physiology .Vol. 23 No.1 pp. 86-88 097.

Rajput R P, Kauraw D L, Bhatnagar R K, Bhavsar M, Velayutham M, and Lal R. 2009. Sustainable management of vertisols in central India. Journal of Crop Improvement 23: 119-35.

Ram H., Singh G. 2011. Soybean (Glycine max) growth, productivity and water use under different sowing methods and seeding rates in Punjab, Indian journal of Agronomy, 56 (4): 377-380

Ramesh A, Joshi O P and Billore S D. 2006. Moisture and nutrient management in Vertisols for sustainable soybean production. Paper presented in workshop on "Soil and Water Management Techniques for Growth and Stability of Agricultural Production held on 14.02.2006 at Central Institute for Agricultural Engineering, Bhopal and organized by Department of Irrigation and Drainage, Central Institute for Agricultural Engineering, Bhopal. Pp. 55-58.

Ramesh A, Joshi O P, Billore S D, and Singh D V. 2007. Impact of integrated soil moisture and nutrient management technologies on soil organic carbon storage in Vertisols under soybean. Paper presented in -National Seminar on Changing Global Vegetable Oils Scenario: Issues and Challenges before India, held on 29-31 January 2007 at DOR, Hyderabad, organized by Indian Society of Oilseeds Research

Raut, V. M., Taware, S.P. and Varghese, P. 2000. Comparison of different sowing methods in soybean. Journal of Maharashtra Agricultural University 25: 218-219.

Raut, V.M., Taware, S.P., Halvankar, G.B. and Varghese, P. 2000. Comparison of different sowing methods in soybean. Journals of Maharashtra Agricultural universities 25(2):218-219

Sharma Purushottam, B.U. Dupare and Ram Manohar Patel (2016. Soybean 
improvement through research in India and socio-economic changes. Legume Research, 39 (6): 935-945

Singh DevVrat, Vyas A K, Gupta G K, Ramteke $\mathrm{R}$ and Khan I R 2011. Tractor-drawn broad bed furrow seed drill machine to overcome moisture stress for soybean (Glycine max) in vertisols. Indian Journal of Agricultural Sciences, 81 (10): 941-944.

Singh Devvrat, Rajkumar Ramteke, A K Vyas, And I R Khan 2012. Sweep seed drill for intercultural operation along with sowing of soybean (Glycine max) crop. Indian Journal of Agricultural Sciences 82 (2): $158-60$

Singh Devvrat, Rajkumar Ramteke, A K Vyas, S D Billore And I R Khan 2012. Tractor Operated Furrow Irrigated Raised Bed System (FIRBS)Seed Drill for Rainfed Soybean in Vertisols. Soybean Research 10 (1): 88-92

Singh Piara, Alagarswamy G, Pathak P, Wani S P, Hoogenboom G and Virmani S M. 1999. Soybean-chickpea rotation on Vertic Inceptisols I. Effect of soil depth and landform on light interception, water balance and crop yields. Field Crops Research 63: 211-24.
Singh SRK, Anupam Mishra, Sonam Agrawal, A A Raut, Prem Chand and A K Dixit 2019. Impact of Better management practices on performance of Soybean In Madhya Pradesh Soybean Research 17 (1 \& 2)): 54-61-92

Singh, J., Kumari, A., Jain, R. and Pachlaniya, N. 2018. Effect of different land configuration on the yield of soybean (Glycine max L.). Int. J. Agric. Engg., 11(1): 135-137.

Tisdall, J. M. and Hodgson, A.S. 1990. Ridge tillage in Australia: A review. Soil \& Tillage Research 18: 127-44.

Tomar RKS (2012. Effect of insitu moisture conservation on yield of soybean under erratic rainfall situation of Bundelkhand Zone of MP. Extended summaries Vol. 3, $3^{\text {rd }}$ International Agronomy Congress ,Nov. 26-30,2012, New Delhi

Tomar S.S. and S.K. Sharma. 2011.Measures for enhancing crop productivity and resource use efficiency in rainfed Vertisols of central.JNKVV Res J 45(1): 19-29

Verma P D, Parmanand, V Jain and A S Rajput 2018. Evaluation of Sowing Methods of Soybean in Bhatapara District of Chhattisgarh. J Krishi Vigyan, 6(2) : 109112 .

\section{How to cite this article:}

Dhakad. S. S., K. V. Ramana Rao, Vinod K. Bhargava, Gayatri Verma, G. R. Ambawatia, Vijay Agrawal, Sanjeev Verma and Tomar. R. K. S. 2020. Effect of Different Sowing Methods on the Growth Characters and Yield of Soybean in Vertisol - A Review. Int.J.Curr.Microbiol.App.Sci. 9(05): 1607-1618. doi: https://doi.org/10.20546/ijcmas.2020.905.182 